\title{
KETENTUAN TENTANG STANDAR PELAYANAN MINIMAL BIDANG KELUARGA BERENCANA DAN KELUARGA SEJAHTERA BERDASARKAN ASAS PERIKEMANUSIAAN DAN HAK ASASI MANUSIA
}

\author{
Riyanti, Agnes Widanti dan Alma Lucyati \\ riyanti@gmail.com \\ Magister Hukum Kesehatan \\ Universitas Katolik Soegijapranata Semarang
}

\begin{abstract}
ABSTRAK
Program keluarga berencana merupakan salah satu upaya pemerintah dalam menangani permasalahan kependudukan yang dialami negara Indonesia, berbagai peraturan telah disusun, salah satunya adalah Ketentuan tentang Standar Pelayanan Minimal Bidang Keluarga Berencana dan Keluarga Sejahtera di Kabupaten/Kota. Peraturan ini disusun untuk mendekatkan pelayanan dan meningkatkan kualitas pelayanan program keluarga berencana dan keluarga sejahtera.Asas perikemanusiaan dan hak asasi manusia dalam ketentuan tentang standar pelayanan minimal bidang keluarga berencana dan keluarga sejahtera belum terlaksana secara nyata, sehingga perlu diteliti bagaimana gambaran hubungan ketentuan tentang standar pelayanan minimal bidang keluarga berencana, keluarga sejahtera dengan asas perikemanusiaan dan hak asasi manusia.

Metode penelitianyang digunakan dalam tesis ini adalah deskriptif analitis dengan metode pendekatan yuridis normatif. Jenis data adalah data sekunder dengan bahan, hukum primer, sekunder dan tersier.Metode pengumpulan data yang dipergunakan adalah studi kepustakaan dengan metode kualitatif normatif.

Hasil penelitian, ketentuan tentang standar pelayanan minimal bidang keluarga berencana, keluarga sejahtera dan asas perikemanusiaan dengan hak asasi manusia sangat berhubungan keterbatasan lingkup pelayanan dan standar pelaksanaan Komunikasi Informasi dan Edukasi yang tidak jelasberdampak pada tidak dipenuhinya hak asasi manusia untuk mendapatkan kesetaraan dan kebebasan dalam pelayanan keluarga berencana dan keluarga sejahtera.
\end{abstract}

Kata kunci : Standar Pelayanan Minimal Bidang Keluarga Berencana Dan Keluarga Sejahtera, Asas Perikemanusiaan, Hak Asasi Manusia 


\section{PENDAHULUAN}

\section{Latar Belakang Masalah}

Pengendalian kuantitas penduduk untuk menjamin tercapainya penduduk tumbuh seimbang antara lain diupayakan melalui program Keluarga Berencana. Upaya pengendalian pertumbuhan penduduk tersebut terus dipertahankan sebagai langkah penting dalam mencapai pembangunan berkelanjutan serta untuk mengembangkan dan meningkatkan kualitas penduduk melalui perwujudan keluarga kecil berkualitas.

Program Keluarga Berencana di Indonesia telah berhasil menurunkan angka kelahiran total (Total Fertility Rate) dari 5,6 anak per wanita usia subur pada awal tahun 70-an menjadi sekitar 2,3 - 2,6 anak per wanita usia subur pada tahun $2007^{1}$ walaupun demikian, berbagai permasalahan yang berkaitan dengan kependudukan tetap ada, seperti masih besarnya pertambahan jumlah penduduk serta tingginya angka laju pertumbuhan penduduk Indonesia tahun 2010 dimana jumlah penduduk pada tahun 2010 meningkat menjadi 237,6 juta jiwa. Sementara itu angka laju pertumbuhan penduduk pada tahun 2010 sebesar 1,49 persen lebih tinggi dibandingkan tahun 2000 yaitu sebesar 1,45 persen. $^{2}$

Semakin banyak anak terutama di kalangan keluarga miskin akan menurunkan kualitas keluarga dan pada akhirnya menurunkan kualitas masyarakat dan bangsa. Berdasarkan data Indeks Pembangunan Manusia/IPM (Human Development Index/HDI Report 2013), Indonesia menempati urutan ke-121 dari 186 negara yang dikaji ${ }^{3}$. Berbagai kondisi ini dikhawatirkan akan melahirkan sebuah generasi yang hilang (lost of generations), yakni sebuah generasi yang tidak mampu berkontribusi dan hanya menjadi beban bagi bangsa dan negara.

Program Keluarga Berencana di Indonesia, seperti juga di negara berkembang lainnya, lebih menekankan pada pencapaian tujuan demografis yakni untuk mencapai target penurunan laju pertumbuhan penduduk. Keluarga Berencana lebih sebagai pengendalian populasi yang memberi jalan bagi negara untuk mengatur fungsi reproduktif warganya khususnya alat reproduksi perempuan. Karena itu program Keluarga Berencana di era orde baru dinilai mengabaikan hak dan kesehatan reproduksi perempuan demi mengejar target pengendalian jumlah penduduk. ${ }^{4}$

Pemerintah Indonesia telah mengadopsi paradigma dunia internasional yang bergerak dibidang kesehatan reproduksi bahwa Keluarga Berencana merupakan hak perempuan dan bukan paksaan, melalui peraturan perundangan-undangan yang disusun tentang kependudukan.

Undang-undang nomor 52 tahun 2009 Tentang Perkembangan Kependudukan dan Pembangunan Keluarga dengan tujuan mewujudkan penduduk tumbuh seimbang dan keluarga berkualitas, melalui upaya pengendalian angka kelahiran dan penurunan angka kematian. Pengendalian kuantitas penduduk dilakukan untuk mewujudkan keserasian, keselarasan, dan keseimbangan antara jumlah penduduk dengan lingkungan hidup baik yang berupa daya dukung alam maupun daya tampung lingkungan serta kondisi perkembangan sosial, ekonomi dan budaya, sehingga dalam perkembangannya, perkembangan kependudukan dan pembangunan keluarga didasarkan pada asas perikemanusiaan.

Dalam upaya meningkatkan pelayanan di bidang Keluarga Berencana, Badan Koordinasi Keluarga Berencana Nasional juga telah menetapkan Peraturan Kepala BKKBN Nomor 55/HK010/B5/2010 tentang Standar Pelayanan Minimal Bidang Keluarga Berencana dan Keluarga Sejahtera di Kabupaten/Kota, untuk dapat memperhatikan potensi dan kemampuan masing-

\footnotetext{
1 Badan Pusat Statistik dan Macro International, 2008, Survey Demografi dan Kesehatan Indonesia 2007, Calverton, Maryland USA, BPS dan Macro International.

2 BKKBN, 2012, Evaluasi Pelaksanaan Program Kependudukan dan KB Tahun 2011, Jakarta :BKKBN, hal. 1.

3 UNDP, 2013, Human Development report 2012 sustainability and equity: a better future for all, New York.

4 Sri Yuliani,2006, Perempuan dan Kebijakan Pengendalian Kelahiran, Jurnal Penduduk dan Pembangunan, LIPI.go.id
} 
masing daerah, dan dengan tetap mempertimbangkan kebutuhan ber-Keluarga Berencana masyarakat di daerah.

Pelaksanaan SPM bidang KB dan KS juga berkaitan dengan peningkatan kesejahteraan keluarga dengan dipenuhinya 3 kebutuhan yaitu: kebutuhan dasar (sandang, pangan, papan dan kesehatan), kebutuhan sosial psikologis (pendidikan, rekreasi, transportasi, interaksi sosial internal dan eksternal) dan kebutuhan pengembangan (tabungan, pendidikan khusus, akses terhadap informasi). ${ }^{5}$

Pada kenyataannya kebijakan-kebijakan tersebut hanya sebatas peraturan tertulis yang menjadi pedoman tanpa direalisasikan dengan pelaksanaan yang nyata. Hal ini terbukti dengan jumlah penduduk yang semakin besar, kualitas sumber daya manusia yang rendah, laju pertumbuhan penduduk yang tinggi, disparitas Total Fertilitiy Rate masih tinggi, unmeet need yang tinggi, kesertaan dalam metode kontrasepsi jangka panjang yang rendah dan angka kematian ibu yang tinggi. Kondisi ini berdampak pada lambatnya peningkatan kesejahteraan keluarga dan masyarakat, sulitnya penanggulangan kemiskinan, meningkatnya masalah ketenagakerjaan dan berbagai masalah kesehatan.

Peraturan Kepala BKKBN nomor 55 tahun 2010 tentang tentang Standar Pelayanan Minimal Bidang Keluarga Berencana dan Keluarga Sejahtera di Kabupaten/Kota merupakan tindaklanjut dari Undang-undang nomor 32 tahun 2004 tentang Pemerintah Daerah Pasal 11 dan pasal 16 dan Peraturan Pemerintah nomor 65 tahun 2005 tentang Pedoman Penyusunan dan Penerapan Standar Pelayanan Minimal serta Peraturan Menteri serta Peraturan Menteri Dalam Negeri nomor 6 tahun 2007 tentang Petunjuk Teknis Penyusunan dan Penetapan Standar Pelayanan Minimal. Tetapi peraturan perundang-undangan yang sudah ditetapkan pemerintah pusat yaitu Undang-undangnomor 32 tahun 2004 tentang Pemerintah Daerah dan Peraturan Pemerintah nomor 65 tahun 2005 tentang Pedoman Penyusunan dan Penerapan Standar Pelayanan Minimal serta Peraturan Menteri serta Peraturan Menteri Menteri Dalam Negeri nomor 6 tahun 2007 tentang Petunjuk Teknis Penyusunan dan Penetapan Standar Pelayanan Minimal baru ditindaklanjuti pelaksanaannya oleh BKKBN tahun 2010.

Pelayanan bidang Keluarga Berencana dan keluarga sejahtera merupakan bagian yang tak terpisahkan dari kesehatan reproduksi, ICPD 1994 telah mengakui tentang hak-hak reproduksi.Masalah hak reproduksi merupakan bagian dari masalah hak asasi manusia dan perikemanusiaan yang harus dipenuhi. Pemenuhannya merupakan bentuk perlindungan bagi setiap individu, serta prakondisi untuk memperoleh hak-hak lainnya seperti hak untuk hidup, hak atas kesejahteraan dan mempertahankan kehidupanannya.Perikemanusiaan atau kemanusiaan adalah sifat yang dimiliki setiap manusia. Manusia pada dasarnya adalah sama dan mempunyai nilainilai kemanusiaan yang bersifat universal. Dengan menjunjung tinggi hak asasi manusia yang luhur dan berbudi pekerti kemanusiaan yang luhur. Segala perbedaan yang tampak tidaklah boleh dijadikan alasan untuk bertentangan dengan nilai-nilai kemanusiaan.Asas Perikemanusiaan mengakui akan persamaan derajat, persamaan hak dan kewajiban antara sesama manusia, pengembangan sikap tenggang rasa dan tepo seliro serta menjunjung tinggi nilai kemanusiaan. ${ }^{6}$

Undang-undangNomor39 tahun 1999 tentang Hak Asasi Manusia menyatakan bahwa hak asasi manusia adalah seperangkat hak yang melekat pada hakikat dan keberadaan manusia sebagai mahluk Tuhan Yang Maha Esa dan merupakan anugrah-Nya yang wajib dihormati, dijunjung tinggi dan dilindungi oleh negara hukum, pemerintahan, dan setiap orang demi kehormatan serta perlindungan harkat dan martabat manusia. Hak asasi manusia harus dijunjung tinggi sebagai secara kodrati melekat pada dan tidak terpisahkan dari manusia, yang harus

\footnotetext{
5 Sunarti E, 2011, Kependudukan dan Keluarga Sejahtera, Isu Strategis Dalam Analisis Dampak Kependudukan Terhadap Aspek Sosial Ekonomi, BKKBN, hal.1.

6 Kementrian Pendidikan dan Kebudayaan, 2013, Materi Ajar Mata Kuliah Pancasila, Jakarta: Kemendikbud, hal. 36.
} 
dilindungi, dihormati, dan ditegakkan demi martabat kemanusiaan, kesejahteraan, kebahagiaan, dan kecerdasan serta keadilan.

Berbagai permasalahan kependudukan yang dihadapi bangsa Indonesia khususnya dalam pelaksanaan Standar Pelayanan Minimal bidang Keluarga Berencana dan Keluarga Sejahtera di Kabupaten/Kota yang belum mampu memenuhi target yang diinginkan dan belum semua masyarakat merasakan keluarga yang sejahtera dimana semua ini merupakan bagian dari nilainilai perikemanusiaan dan hak asasi manusia yang harus ditegakkan, dijunjung tinggi dan dilindungi.

\section{Perumusan Masalah}

Berdasarkan latarbelakang di atas, maka dalam dirumuskan masalah sebagai berikut:

1. Bagaimana ketentuan tentang Standar Pelayanan Minimal Bidang Keluarga Berencana dan Keluarga Sejahtera di Kabupaten/Kota?

2. Bagaimana asas perikemanusiaan dan hak asasi manusia?

3. Bagaimana hubungan ketentuan tentang Standar Pelayanan Minimal Bidang Keluarga Berencana, Keluarga Sejahtera di Kabupaten/Kota dengan asas perikemanusiaan dan hak asasi manusia?

\section{Metode Penelitian}

Metode penelitian yang digunakan dalam menjawab permasalahan ini adalah metode penelitian yuridis normatif, penelitian hukum normatif merupakan penelitian kepustakaan, yaitu: penelitian terhadap data sekunder. Spesifikasi penelitian yang digunakan adalah deskriptif anaitis yaitu membuat deskripsi atau gambaran secara sistematis, faktual dan akurat mengenai fakta, sifat dan hubungan antar fenomena atau gejala yang diteliti sambil menganalisanya, yaitu mencari sebab akibat dari suatu hal dan menguraikannya secara konsisten dan sistematis serta logis. Analisis data penelitian ini adalah metode kualitatif normatif. Metode ini akan menganalisis data-data sekunder dalam bentuk kalimat yang konsisten, logis, efektif, dan sistematis. Jenis data yang digunakan data sekunder yaitu data yang diperoleh peneliti dari penelitian kepustakaan dan dokumentasi, yang merupakan hasil penelitian dan pengolahan orang lain, yang sudah tersedia dalam bentuk buku-buku atau dokumentasi yang biasanya disediakan di perpustakaan umum atau perpustakaan milik pribadi.

\section{PEMBAHASAN}

\section{Ketentuan Tentang Standar Pelayanan Minimal Bidang Keluarga Berencana DanKeluarga Sejahtera}

Standar Pelayanan Minimal Bidang Keluarga Berencana dan Keluarga Sejahtera merupakan tolok ukur kinerja pelayanan keluarga berencana dan keluarga sejahtera yang diselenggarakan pemerintah daerah kabupaten/kota dengan tujuan untuk memenuhi kebutuhan masyarakat dalam mendapatkan pelayanan KB dan Keluarga Sejahtera. Hal ini dilaksanakan dalam upaya meningkatkan taraf kesejahteraan masyarakat di daerah.

"Undang-undang Dasar 1945 Pasal 28 H ayat (1) yang menyatakan bahwa Setiap orang berhak hidup sejahtera lahir dan batin, bertempat tinggal, dan mendapatkan lingkungan hidup yang baik dan sehat serta berhak memperoleh pelayanan kesehatan".

Penyusunan SPM bidang Keluarga Berencana dan Keluarga Sejahtera di Kabupaten/Kota telah sesuai dengan Peraturan Pemerintah nomor 65 tahun 2005 tentang Pedoman Penyusunan dan Penerapan Standar Pelayanan Minimal Pasal 2 ayat (1) yang menyatakan bahwa Pedoman penyusunan dan penerapan SPM menjadi acuan dalam penyusunan SPM oleh Menteri/Pimpinan 
Lembaga Pemerintah Non Departemen dan dalam penerapannya oleh Pemerintah Provinsi dan Pemerintah Kabupaten/Kota. Pasal 4 ayat (3) yang menyatakan bahwa dalam penyusunan SPM sebagaimana dimaksud ayat (1) ditetapkan jenis pelayanan dasar, indikator SPM dan batas waktu pencapaian SPM.Pasal 8 ayat (2) menyatakan bahwa untuk mendukung penerapan SPM, Pimpinan Lembaga Pemerintah Non-Departemen menyusun petunjuk teknis yang ditetapkan dengan Peraturan Menteri terkait.

BKKBN telah menyusun petunjuk teknis SPM bidang Keluarga Berencana dan Keluarga Sejahtera di Kabupaten/Kota dengan menetapkan pengertian, definisi operasional, cara perhitungan, sumber data, rujukan, target, langkah-langkah kegiatan, Sumber Daya Manusia, dan penanggung jawab dari kegiatan yang akan dilaksanakan.

Adanya standard pelayanan minimal sangat diperlukan baik bagi Pemerintah daerah maupun bagi masyarakat sebagai konsumen. Bagi Pemerintah daerah adanya standard pelayanan minimal dijadikan tolok ukur (benchmark) dalam penentuan biaya yang diperlukan untuk penyediaan pelayanan tersebut. Peraturan Menteri Dalam Negeri nomor 6 tahun 2007 tentang Petunjuk Teknis Penyusunan dan Penetapan Standar Pelayanan Minimal Pasal 14 yang menyatakan bahwa Penyusunan rekomendasi penetapan SPM oleh Dewan Pertimbangan Otonomi Daerah sebagaimana dimaksud dalam Pasal 12 ayat (1) huruf e butir c mempertimbangkan kemampuan keuangan pemerintah dan pemerintahan daerah dalam melaksanakan urusan wajib dengan SPM pelayanan dasar yang bersangkutan. Sedangkan bagi masyarakat sebagai acuan bagi untuk menilai kualitas dan kuantitas suatu pelayanan publik yang disediakan oleh pemerintah daerah.Adanya SPM akan menjamin minimum pelayanan yang berhak diperoleh masyarakat dari Pemerintah. Disamping SPM kewenangan wajib, Daerah dapat mengembangkan dan menerapkan standard kinerja untuk kewenangan Daerah yang lain. Dengan adanya SPM maka diharapkan akan terjadi pemerataan pelayanan publik dan menghindari kesenjangan pelayanan antar daerah.

Permasalahan yang dihadapi meskipun Standar Pelayanan Minimal bidang Keluarga Berencana dan Keluarga Sejahtera di Kabupaten/Kota telah disusun sejak tahun 2010 tetapi pemerintah daerah hingga saat ini belum mampu mengupayakan program Keluarga Berencana dan Keluarga Sejahtera sebagai prioritas pembangunan di daerah, hal ini dibuktikan masih banyak daerah dengan pencapaian target cakupan pelayanan Keluarga Berencana dan Keluarga Sejahtera belum mencapai target dari standar pelayanan minimal yang ditetapkan pemerintah daerah dan pemerintah pusat. Tidak tercapainya program Keluarga Berencana dan Keluarga Sejahtera sebagai prioritas pembangunan di daerah salah satunya disebabkan kepentingan politik para pemegang kebijakan yang berbeda di daerah kabupaten/kota.

Sesuai dengan Peraturan Pemerintah Nomor 6 tahun 2005 tentang Pedoman Penyusunan dan Penerapan Standar Pelayanan Minimal Pasal 19 ayat (1) yang menyatakan bahwa Pemerintah dapat memberikan sanksi kepada Pemerintahan Daerah yang tidak berhasil mencapai SPM dengan baik dalam batas waktu yang ditetapkan dalam Peraturan Menteri sebagaimana dimaksud dalam Pasal 9 ayat (3) berdasarkan hasil monitoring dan evaluasi sebagaimana dimaksud dalam Pasal 15 dengan mempertimbangkan kondisi khusus Daerah yang bersangkutan. Sanksi tersebut masih belum dapat terlaksana karena batas waktu pencapaian target masih tersedia dan diharapkan daerah dapat menggunakan kesempatan ini untuk menyelenggarakan pelayanan semaksimal mungkin.

Dari tiga hal yang menjadi fokus Standar Pelayanan Minimal bidang Keluarga Berencana dan Keluarga Sejahtera di Kabupaten/Kota yaitu: pertama pelayanan Komunikasi, Informasi dan Edukasi (KIE) yang meliputi cakupan pasangan usia subur (PUS) yang istrinya di bawah usia 20 tahun, cakupan sasaran PUS menjadi peserta KB aktif, cakupan PUS yang ingin ber-KB tidak terpenuhi (unmet need), cakupan nggota kelompok balita (BKB) ber-KB, cakupan PUS anggota Usaha Peningkatan Pendapatan Keluarga Sejahtera (UPPKS) yang ber-KB, ratio Petugas 
Lapangan Keluarga Berencana/Penyuluh Keluarga Berencana (PLKB/PKB) di setiap desa/kelurahan, dan ratio Pembantu Pembina Keluarga Berencana Desa (PPKBD) disetiap desa/kelurahan. Kedua, penyediaan alat dan obat kontrasepsi meliputi cakupan penyediaan alat dan obat kontrasepsi untuk memenuhi permintaan masyarakat. Ketiga, penyediaan informasi dan data mikro yang meliputi cakupan informasi data mikro keluarga disetiap desa.Kegiatan KIE memiliki banyak lingkup pelayanan.

Adapun hasil yang telah dicapai hingga tahun 2012 adalah sebagai berikut: ada 20 provinsi di Indonesia yang pencapaian CPR atau cakupan sasaran PUS menjadi peserta KB aktif kurang dari $65 \%$, seluruh provinsi (33 provinsi) dengan tingkat unmeet need diatas 5\%, ada 8 provinsi dengan penyediaan informasi dan data mikro kurang dari 100\%, pada tahun 2012. Kelompok UPPKS dari 33 provinsi 9 diantaranya tidak mencapai sasaran dan 15 provinsi tidak mencapai sasaran keluarga pra sejahtera dan keluarga sejahtera I. Untuk penyediaan alat dan obat kontrasepsi ada 8 provinsi yang melaporkan persediaan alat dan obat untuk kabupaten/kota kurang 100\% pada tahun 2011. ${ }^{7}$ Peraturan Kepala BKKBN nomor 55/HK-010/B5/2010 tentang Standar Pelayanan Minimal Bidang Keluarga Berencana dan Keluarga Sejahtera di Kabupaten/Kota Pasal 2 ayat (2) menyatakan tentang SPM bidang Keluarga Berencana dan Keluarga Sejahtera meliputi jenis pelayanan dasar beserta indikator kinerja dan target tahun 20102014, demikian pula Peraturan Menteri Kesehatan RI nomor 741/Menkes/PER/VII/2008 tentang Standar Pelayanan Minimal Bidang Kesehatan di Kabupaten/Kota Pasal 2 ayat (2) yang menyatakan bahwa SPM kesehatan yang meliputi jenis pelayanan beserta indikator kinerja dan target tahun 2010 - tahun 2015 ; huruf a butir (12) cakupan peserta KB aktif 70\% pada tahun 2010.

Pencapaian hasil pelayanan KB dan Keluarga Sejahtera yang rendah ini disebabkan keterlambatan waktu dalam menyusun SPM Bidang KB dan KS di Kabupaten/Kota oleh pemerintah pusat. Peraturan yang telah dicanangkan pemerintah dalam Undang-undang nomor 32 tahun 2004 tentang Pemerintah Daerah Pasal 11 dan 16 yang menyatakan bahwa bidang kesehatan termasuk pelayanan KB dan Keluarga Sejahtera merupakan urusan wajib yang berpedoman pada standar pelayanan minimal, Peraturan Pemerintah nomor 65 tahun 2005 tentang Pedoman Penyusunan Standar Pelayanan Minimal serta Peraturan Menteri Dalam Negeri nomor 6 Tahun 2007 tentang Petunjuk Teknis Penyusunan dan Penetapan Standar Pelayanan Minimal baru ditanggapi oleh BKKBN pada tahun 2010. Seharusnya amanat dari peraturan perundang-undangan tentang standar pelayanan segera ditindaklanjuti oleh menteri/lembaga pemerintah non-departemen termasuk dalam hal ini BKKBN sebagai pemegang kebijakan di pusat.

Dengan adanya Standar Pelayanan Minimal bidang Keluarga Berencana dan Keluarga Sejahtera, terbukti ada banyak kabupaten/kota yang merasa kewalahan melaksanakannya. Hal ini terjadi karena beberapa sebab diantaranya kondisi petugas lapangan yang kurang, tidak terpenuhinya kebutuhan alat dan obat kontrasepsi karena dana yang dipersiapkan daerah kurang bahkan tidak ada. ${ }^{8}$ Demikian pulaperan dan partisipasi kaum pria dalam program KB dan Keluarga Sejahtera juga hingga saat ini masih dirasakan rendah. Padahal, keluarga berencana merupakan komitmen berdua, suami dan istri. Pada kenyataannya, selama ini hanya perempuan yang dominan menggunakan alat dan obat kontrasepsi. Ketimpangan ini yang sering dijadikan permasalahan pada berbagai pertemuan bidang kependudukan dan Keluarga Berencana.

Selama ini ada banyak faktor yang mempengaruhi pelaksanaan SPM bidang KB dan KS selain program KB tidak diprioritaskan, kerancuan mengenai SPM Bidang KB dan KS juga menyebabkan sulitnya penganggaran bagi unit penyedia pelayanan, sehingga dalam penentuan alokasi anggarannya diwarnai dengan bargaining antara unit/instansi pengelola pelayanan

7 BPS, BKKBN, Kementerian Kesehatan, 2013. Survey Demografi dan Kesehatan Indonesia 2012. Calverton, Maryland USA, BPS dan Macro International.

8 Mustakim, 2012, Cakrawala KB Kependudukan dan Pemberdayaan Keluarga, Jakarta : Referensi, hal.226. 
dengan pihak yang mempunyai otoritas anggaran dan perencanaan. Akibatnya biaya untuk setiap pelayanan (cost of service) tidak dapat dideteksi yang kemudian menyebabkan biaya keseluruhan pelayanan (agregat cost of services) sulit diketahui. Inilah penyebab utama Pemda kesulitan dalam menentukan jumlah dana (fiscal need) yang dibutuhkan untuk membiayai penyelenggaraan pemerintahan Daerah. ${ }^{9}$

Perka BKKBN Nomor 55 tahun 2010 pada pasal 5 ayat (1) menyatakan bahwa Standar Pelayanan Minimal bidang Keluarga Berencana dan Keluarga Sejahtera di Kabupaten/Kota merupakan acuan dalam penyusunan Rencana Pembangunan Jangka Menengah Daerah (RPJMD) untuk pencapaian target SPM di masing-masing Daerah Kabupaten/Kota.

Dalam pasal tersebut di atas jelas dinyatakan bahwa yang melaksanakan Standar Pelayanan Minimal bidang Keluarga Berencana dan Keluarga Sejahtera adalah pemerintah daerah kabupaten/kota, sehingga diperlukan upaya yang serius dari pemerintah daerah kabupaten/kota untuk dapat mencapai sasaran target yang diharapkan dalam SPM bidang KB dan KS. Sebagai contoh di provinsi Jawa Barat melalui Peraturan Daerah nomor 10 tahun 2008 tentang Urusan Pemerintahan Provinsi Jawa Barat Pasal 3 ayat (1) yang menyatakan bahwa bidang Keluarga Berencana dan Keluarga Sejahtera merupakan salah satu urusan wajib pemerintah daerah. Pada pasal 4 menyatakan penyelenggaraan urusan wajib tersebut berpedoman pada standar pelayanan minimal yang ditetapkan sesuai ketentuan peraturan perundang-undangan. Menindaklanjuti Perka BKKBN no 55/HK-010/B5/2010 tentang Standar Pelayanan Minimal Bidang Keluarga Berencana dan Keluarga Sejahtera di Kabupaten/Kota, Pemerintah Kota Bekasi menerbitkan Peraturan Walikota Bekasi nomor 53 tahun 2012 tentang Standar Pelayanan Minimal Bidang Keluarga Berencana dan Keluarga Sejahtera Kota Bekasi, peraturan tersebut disusun sesuai dengan peraturan kepala BKKBN nomor 55/HK-010/B5/2010 termasuk indikator dan target yang ingin dicapai.

Berbagai upaya telah dilakukan pemerintah baik dari pembuatan peraturan maupun daripelayanan (pemberi pelayanan dan juga penerima pelayanan). Standar Pelayanan Minimal Bidang Keluarga Berencana dan Keluarga Sejahtera memang sebaiknya dipikirkan dan menjadi prioritas dalam pembangunan didaerah,karena berdampak pada berbagai permasalahan kependudukan.

\section{Asas Perikemanusiaan Dan Hak Asasi Manusia Dalam Pelayanan KB Dan Keluarga Sejahtera}

Undang-undang Nomor 52 tahun 2009 Tentang Perkembangan kependudukan dan Pembangunan keluarga juga telah mengatur dengan jelas tentang keluarga berencana dan pelayanan yang dilaksanakan yang berasaskan perikemanusiaan untuk penduduk tumbuh seimbang dan keluarga berkualitas, keluarga yang bertanggung jawab. pelayanan Keluarga Berencana dan Keluarga Sejahtera yang sesuai dengan output Standar Pelayanan Minimal bidang Keluarga Berencana dan Keluarga Sejahtera akan tercapai.

Pelayanan keluarga berencana dan keluarga sejahtera dilaksanakan untuk membantu calon atau pasangan suami istri dan keluarga dalam mengambil keputusan dan mewujudkan hak asasinya khususnya hak reproduksi dan hak untuk hidup layak secara bertanggung jawab tentang: usia perkawinan yang ideal; usia melahirkan yang ideal; jumlah anak yang ideal; jarak kelahiran anak yang ideal; serta upaya mencapai keluarga yang sejahtera.

Undang-undang Nomor 52 tahun 2009 Tentang Perkembangan kependudukan dan Pembangunan Keluarga pasal 1 menyatakan bahwa pembangunan keluarga berasaskan perikemanusiaan, yang dimaksudkan asas perikemanusiaan bahwa kebijakan dalam pembangunan keluarga dalam hal ini program keluarga berencana dan keluarga sejahtera harus didasarkan pada Ketuhanan Yang Maha Esa dengan memperhatikan nilai-nilai kemanusiaan.

9 Kemitraan bagi Pembaruan Tata Pemerintahan,2009,Belajar Dari 10 Provinsi, Cet.I. Jakarta : Kemitraan,hal.16 
Asas perikemanusiaan menjelaskan bahwa setiap kegiatan dalam program pembangunan dilaksanakan berdasarkan pada nilai-nilai manusiawi secara universal. Manusia yang terdiri dari tubuh, jiwa dan aspek kerohanian secara bersama-sama akan menjalankan fungsi kemanusiaan yang dimiliki setiap orang. Pelayanan KB dan keluarga sejahtera tidak terlepas dari fungsi kemanusiaan yaitu setiap orang hidup, memerlukan fisik yang sehat, keutuhan tubuh, panca indera, imajinasi dan pikiran, afeksi yang sehat (kesehatan emosional), nalar praktis, hidup bersama dan kepedulian terhadap sesama, pengakuan, dan penghargaan sebagai pribadi dalam masyarakat, berelasi harmonis dengan mahluk lain, bermain dan penataan lingkungan sekitar melalui keterlibatan politis dan hak milik pribadi. Berdasarkan fungsi-fungsi kemanusiaan ini manusia menjadi lebih tinggi martabatnya dibandingkan mahluk hidup yang lain.

Pemahaman akan asas kemanusiaan mengandalkan bahwa setiap orang setara dan bebas, sehingga pelayanan KB dan keluarga sejahtera berasaskan perikemanusiaan memberikan implikasi bahwa setiap individu baik laki-laki ataupun perempuan mendapatkan pelayanan dan perlakuan yang sama tanpa diskriminasi dan memiliki kebebasan dalam mengambil keputusan tanpa dipaksakan untuk menjaga dan menjunjung tinggi nilai kemanusiaannya.

Pelayanan keluarga berencana dan keluarga sejahtera merupakan bagian dari kesehatan reproduksi, karena ruang lingkup dari pelayanan kesehatan reproduksi menggunakan pendekatan siklus hidup (life sycle approach). ICPD tahun 1994 di Kairo memberikan definisi kesehatan reproduksi adalah suatu keadaan kesejahteraan fisik, mental, dan sosial yang utuh, dan bukan hanya ditandai dengan tidak adanya penyakit atau kecacatan dalam segala hal yang berhubungan dengan sistem reproduksi dan fungsi-fungsi serta proses-prosesnya. Oleh karena itu, kesehatan reproduksi berarti bahwa orang dapat mempunyai kehidupan seks yang memuaskan dan aman, dan mereka memiliki kemampuan untuk bereproduksi dan kebebasan untuk menentukan keinginannya, kapan dan frekuensinya. ${ }^{10}$

Dalam hal terakhir termasuk, hak laki-laki dan perempuan untuk memperoleh informasi dan mengakses terhadap cara-cara KB yang aman, efektif, terjangkau, dan dapat diterima sebagai pilihannya, serta metoda-metoda lain yang dipilih yang tidak melawan hukum, dan hak untuk memperoleh pelayanan pemeliharaan kesehatan yang tepat, yang memungkinkan para perempuan mengandung dan melahirkan anak dengan selamat, serta kesempatan memiliki bayi yang sehat .

Kesehatan reproduksi tak terpisahkan dengan soal hak reproduksi, kesehatan seksual, dan hak seksual.Hak reproduksi adalah bagian dari hak asasi yang meliputi hak setiap pasangan dan individual untuk memutuskan secara bebas dan bertanggung-jawab jumlah, jarak, dan waktu kelahiran anak, serta untuk memiliki informasi dan cara-cara untuk melakukannya.

Keberadaan manusia tidak dapat dipisahkan dengan hak asasi manusia. Hak Asasi Manusia ada melekat pada manusia, apabila Hak Asasi Manusia dihilangkan berarti hilanglah kemanusiaannya seorang manusia. Oleh karenanya, Hak Asasi Manusia bersifat fundamental maka adanya merupakan keharusan, siapapun tidak dapat mengganggu dan setiap orang harus memperoleh perlindungan Hak Asasi Manusia-nya.Demikian halnya dengan hak reproduksi manusia yang merupakan bagian dari Hak Asasi Manusia yang harus dilindungi dan dihormati.

Keterkaitan antar Hak Asasi Manusia dan hak reproduksi diawali dan dinyatakan dalam Deklarasi Universal Hak Asasi Manusia tahun 1948 bahwa setiap orang memiliki hak kebebasan mencari jodoh dan membentuk keluarga, perkawinan harus dilaksanakan atas dasar suka sama suka (Pasal 16) dan hak kebebasan atas kualitas hidup untuk jaminan kesehatan dan keadaan yang baik untuk dirinya dan keluarganya (Pasal 25). Pernyataan ini didukung pula dalam

10 Ratna Batara Munti, 2010, Mewujudkan Hak Perempuan Atas Kesehatan Reproduksi dan Seksual Sebagai HAM, Jaringan Kerja Prolegnas Pro Perempuan/Federasi LBH APIK 
Undang-undang Nomor 7 Tahun 1984 tentang Konvensi Penghapusan Diskriminasi terhadap WanitaPasal 11 butir $1 \mathrm{f}$, Pasal 11 butir (2), Pasal 12 Pasal 14 butir (2 b), Pasal 16 butir (1). Demikian pula pada Tap. No. XVII/MPR/1998 tentang Hak Asasi Manusia Pasal 2,3, 27 dan pasal 39. UndangUndang Nomor 39 Tahun 1999 tentang Hak Asasi Manusia Pasal 10 menyatakan bahwa setiap orang berhak membentuk suatu keluarga dan melanjutkan keturunan melalui perkawinan yang sah dan Pasal 49 butir (3) menyatakan bahwa hak khusus yang melekat pada diri wanita dikarenakan fungsi reproduksinya, dijamin dan dilindungi oleh hukum.

Pemikiran mengenai hak-hak reproduksi wanita merupakan dari konsep hak asasi manusia. Baik dalam Intenational Conferention of Population and Developtment (ICPD)tahun 1994 mengakui hak-hak reproduksi sebagai bagian yang tak terpisahkan dan hak yang paling mendasar dari kesehatan reproduksi dan seksual. Kondisi reproduksi sehat dapat tercapai bila masyarakat dan negara memberikan penghormatan terhadap pemenuhan hak-hak reproduksi. Pelayanan KB danKesehatan Reproduksi saat ini tidak hanya ditujukan untuk penurunan angka kelahiran namun dikaitkan pula pada dengan tujuan untuk pemenuhan hak-hak reproduksi, promosi, pencegahan, penanganan masalah-masalah kesehatan reproduksi dan seksual serta menjaga kesehatan dan kesejahteraan ibu,bayi dan anak.

\section{Hubungan Standar Pelayanan Minimal Bidang Keluarga Berencana, Keluarga Sejahtera Di Kabupaten/Kota Dengan Asas Perikemanusiaan Dan Hak Asasi Manusia}

Penghormatan, perlindungan, dan pemenuhan atas kesejahteraan sebesar-besarnya bagi rakyat merupakan prinsip yang mendasari mengapa pembangunan dijalankan dan menjadi hak rakyat dan kewajiban pemerintah.Hal ini disebabkan ditataran normatif pada pembukaan dan Pasal-pasal UUD 1945 mengamanatkan secara eksplisit kewajiban dan peran negara.Prinsipprinsip hak dalam perspektif hak asasi manusia bahwa hak merupakan hal yang tak terpisahkan. Semua orang lahir dengan hak yang sama. Hak asasi tidak bisa diambil maupun diserahkan, sifatnya melekat dan universal (semua orang memiliki hak yang sama dimanapun dan sepanjang waktu). Demikian juga dengan hubungan antara negara dan masyarakat.

Hak-hak dasar baik hak sosial-politik maupun hak ekonomi, sosial, dan budaya adalah hak yang mutlak harus dijamin, dilindungi, dan dipenuhi oleh negara. Kewajiban negara dalam upaya pemenuhan hak seringkali ditepis dengan argumen, keterbatasan kemampuan negara dalam memenuhi hak dasar rakyat. Akibatnya, pemerintah akan sepenuhnya menggantungkan kewajibannya pada kemauan negara untuk menyediakannya. Pemahaman ini menyatakan bahwa tugas negara dalam konteks kewajiban mereka untuk memenuhi hak-hak dasar rakyat. Pada titik inilah pemahaman akan hak azasi manusia memiliki makna strategis dalam membangun sebuah standar kemanusiaan yang memanusiakan dan membebaskan.

Standar Pelayanan Minimal Bidang Keluarga Berencana dan Keluarga Sejahtera tentunya tidak akan terlepas dari pemenuhan kebutuhan akan asas perikemanusiaan dan hak asasi manusia. Pelayanan Keluarga Berencana dan Keluarga sejahtera merupakan upaya peningkatan keterpaduan dan peran serta masyarakat, pembinaan keluarga, dan pengaturan kehamilan dengan memperhatikan agama, kondisi perkembangan sosial ekonomi dan budaya, serta tata nilai yang hidup dalam masyarakat disertai komunikasi, informasi dan edukasi.

Hal ini sesuai dengan pemahaman tentang keluarga sejahtera menurut Peraturan Menteri Dalam Negeri Nomor 26 tahun 2009 tentang Pedoman Pelaksanaan Peningkatan Peranan Wanita Menuju Keluarga Sehat dan sejahtera Di Daerah adalah keluarga yang dibentuk berdasarkan atas perkawinan yang sah, mampu memenuhi kebutuhan hidup spiritual, dan materiil yang layak, bertaqwa kepada Tuhan Yang Maha Esa, memiliki hubungan yang serasi, selaras, seimbang antar anggota dan antara keluarga dengan masyarakat dan lingkungan. 
Permasalahan dalam pencapaian standar pelayanan minimal bidang Keluarga Berencana dan Keluarga Sejahtera jika dihubungkan dengan asas perikemanusiaan dan hak asasi manusia saat ini antara lain kebijakan tentang Keluarga Berencana yang bertujuan menyeimbangkan jumlah penduduk dengan daya tampung alam masih menjadi tujuan utama pemerintah, sehingga salah satu target yang dikejar adalah jumlah akseptor Keluarga Berencana untuk menekan laju pertumbuhan penduduk yang berakibat terlupakannya kualitas dari pelayanan Keluarga Berencana dan keluarga sejahtera untuk memenuhi hak dasar manusia.

Pelayanan keluarga berencana dan keluarga sejahtera sangat penting, sehingga perlu dilaksanakan dengan benar secara profesi maupun hukum guna kepentingan masyarakat. Dengan diberlakukannya Peraturan KepalaBKKBN Nomor 55/HK-010/B5/2010 tentang Standar Pelayanan Minimal Bidang Keluarga Berencana dan Keluarga Sejahtera di Kabupaten/Kota diharapkan pelayanan yang diberikan dapat dirasakan oleh semua lapisan masyarakat. Dan diharapkan semua lini yang terlibat dalam pelayanan keluarga berencana dan keluarga sejahtera dapat melaksanakannya sesuai dengan peraturan hak asasi manusia khususnya hak reproduksi perempuan yang selama ini selalu menjadi konsumen terbanyak dalam program Keluarga Berencana.

Jika diperhatikan apa yang menjadi cita-cita keluarga berencana dan keluarga sejahtera merupakan upaya pemenuhan asas perikemanusiaan yang tidak terlepas pula untuk memenuhi hak asasi manusia. Tetapi ketika suatu standar pelayanan minimal dihadirkan sebagai upaya pemerintah mendekatkan pelayanan kepada masyarakat dengan tujuan akhir adanya batas pencapaian suatu target. Sedangkan program ini terkait dengan hak-hak asasi seseorang khususnya hak reproduksi dan hak untuk hidup layak, hak kesejahteraan, hak atas keadilan termasuk pula hak perempuan tentunya tidak dapat dipaksakan.

Salah satu bukti yang menunjukkan adanya tujuan pemerintah untuk memaksakan tujuannya dibandingkan memenuhi hak kesehatan reproduksi dapat dilihat pada kebijakan tentang Jaminan Persalinan (Jampersal) dengan tujuan menurunkan Angka Kematian lbu yang menyebutkan peserta Jaminan Persalinan mendapatkan pelayanan yang salah satunya adalah pelayanan KB pasca persalinan. Kebijakan ini merupakan salah satu upaya dari pemerintah agar pemakaian alat kontrasepsi yang lebih efektif untuk jangka panjang meningkat. upaya ini jika diperhatikan dari aspek hak asasi manusia merupakan pemaksaan pemerintah pada perempuan dalam menjalankan hak reproduksinya, ketentuan Jaminan Persalinan dengan terang-terangan memberikan pelayanan pada masa pasca persalinan dan perempuan harus membayar bantuan tersebut dengan mengikuti program Keluarga Berencana sebagai akseptor Keluarga Berencana jangka panjang, sehingga Jampersal terkesan pula sebagai alat untuk mengarahkan perempuan dalam membatasi kehamilannya. Seharusnya ketentuan tentang keluarga berencana menjadi aturan yang mengedepankan keselamatan dan keamanan bagi peserta KB dalam mendapatkan hak-hak asasinya tanpa paksaan.

Program KB pada pelaksanaannya lebih banyak menempatkan perempuan sebagai objek. Sejarah keberadaan program keluarga berencana di Indonesia muncul, sudah tertanam citra bahwa Keluarga Berencana adalah untuk perempuan. Citra tersebut relatif sulit bergeser karena telah tertanam cukup lama dalam kehidupan masyarakat. Kaum pria seolah tak acuh terhadap penggunaan alat kontrasepsi karena itu merupakan urusan perempuan. Sehingga sampai saat ini di lingkungan masyarakat masih kental terbangun citra bahwa Keluarga Berencana untuk perempuan. Selain itu hingga ini kebijakan tentang Keluarga Berencana masih bertujuan untuk menyeimbangkan jumlah penduduk sehingga target yang dikejar adalah jumlah akseptor Keluarga Berencana untuk menekan laju pertumbuhan penduduk yang berakibat terlupakannya kualitas dari pelayanan Keluarga Berencana termasuk pula pelayanan keluarga sejahtera. ${ }^{11}$

11 Nung Ati N, 2012, Ketentuan Tentang Keluarga Berencana Dan Asas Nondiskriminasi Dikaitkan Dengan Hak Reproduksi Perempuan, Tesis, Fakultas Hukum Unika Soegijapranata, hal. 61 
Masalah hak reproduksi bukan saja menyangkut aspek kesehatan, tetapi juga aspekaspek lainnya seperti ekonomi, sosial, budaya, pendidikan dan lain-lain.Artinya sulit jika hanya mengharapkan adanya peningkatan kesehatan tanpa adanya peningkatan kesejahteraan ekonomi dan status sosial perempuan oleh karena itu kesadaran dan pengetahuan tentang hakhak reproduksi tersebut penting diketahui perempuan.

Standar Pelayanan Minimal bidang Keluarga Berencana dan Keluarga Sejahtera selain memfokuskan kegiatan pada aspek pelayanan keluarga berencana juga pada aspek kesejahteraan keluarga dengan kegiatan UPPKS dalam bentuk KIE. Dengan memperhatikan lingkup kegiatan SPM bidang KB dan KS, memiliki keterbatasan yaitu hanya pada pendewasaan usia perkawinan, pencapaian akseptor KB, pelayanan bayi, balita, remaja, alat dan obat kontrasepsi, petugas pelaksana, dan informasi. Pembatasan lingkup kegiatan ini berakibat pada pelayanan lain seperti pelayanan pada perempuan dengan gangguan sistem reproduksi tidak tercakup termasuk pula efek samping dari penggunaan kontrasepsi, padahal sebagaimana diketahui bahwa pelayanan kesehatan reproduksi merupakan bagian yang tidak terpisahkan dalam program keluarga berencana. Sebaiknya pemerintah juga perlu memperhatikan kesehatan reproduksi dalam ketentuan tentang SPM bidang keluarga berencana dan keluarga sejahtera.

Dari sisi Komunikasi, Informasi dan Edukasi tentang Keluarga Berencana dan Keluarga Sejahtera dalam SPM bidang KB dan KS ini tidak terlihat bagaimana proses Komunikasi, Informasi dan Edukasi yang memiliki standar yang tepat demikian pula dalam petunjuk teknis dari SPM ini. Sehingga perlu dipikirkan lebih lanjut proses Komunikasi, Informasi dan Edukasi tentang Keluarga Berencana dan Keluarga Sejahtera termasuk penyediaan sarana dan prasarana yang diperlukan dalam proses Komunikasi, Informasi dan Edukasi.

Pelaksanaan pelayanan KB bukan hanya milik pemerintah tetapi lebih juga milik keluarga, sehingga diperlukan suatu kesepakatan antara pasangan suami dan istri untuk merencanakan dan menentukan jumlah anak, jarak anak, usia ideal memiliki anak dan mengatur kehamilan. Asas perikemanusiaan dan hak asasi manusia sangat dibutuhkan dalam upaya pelaksanaan pelayanan Keluarga Berencana dan Keluarga Sejahtera baik antara pemerintah dan masyarakat maupun di dalam keluarga.

Menurut Mustakim (2012) dalam bukunya Cakrawala KB, Kependudukan dan Pemberdayaan Keluarga, diperlukan pendalaman dan pemahaman program KB termasuk ketentuan SPM bidang KB dan KS terutama bagi jajaran pemerintah daerah dan DPRD kabupaten/kota. Sebagian orang menilai, rendahnya anggaran (APBD) untuk program KB di kabupaten/kota adalah salah satunya disebabkan sebagian penentu kebijakan di tingkat kabupaten/kota masih belum memahami akan pentingnya pelaksanaan SPM bidang KB dan KS dalam program KB bagi daerah yang bersangkutan, sehingga program KB bukan prioritas dalam pembangunan daerah. Sebaiknya semua unsur penentu kebijakan mempunyai pandangan jauh ke depan, dan memahami bahwa program KB merupakan investasi jangka panjang untuk masa depan generasi kita. ${ }^{12}$

\section{PENUTUP}

\section{Simpulan}

1. Keterlambatan dalam menindaklanjuti peraturan perundang-undangan tentang penyusunan Standar Pelayanan Minimal dari BKKBN pusat menyebabkan tidak tercapainya target dalam SPM bidang KB dan KS saat ini. Peraturan tentang SPM bidang KB dan KS merupakan ketentuan yang disusun pemerintah pusat agar dilaksanakan oleh pemerintah daerah dalam upaya mendekatkan pelayanan kepada masyarakat, namun ketentuan ini belum dapat

12 Mustakim, op.cit, hal.264 
terlaksana dengan baik dikarenakan pemerintah daerah belum mampu memprioritaskan program KB dan keluarga sejahtera sebagai program pembangunan di daerah.

2. Asas perikemanusiaan dan hak asasi manusia merupakan bagian yang tidak dapat dipisahkan. Asas perikemanusiaan mengakui akan kesetaraan dan kebebasan yang menjadi implikasi dasar dalam Hak Asasi Manusia. Hak Asasi Manusia dalam pelayanan KB dan Keluarga Sejahtera menjamin akan hak reproduksi, termasuk pula hak untuk hidup, hak atas kebebasan, hak atas rasa aman, hak atas kesejahteraan, hak perempuan.

3. Ketentuan tentang Standar Pelayanan MinimalBidang Keluarga Berencana dan Keluarga Sejahtera di Kabupaten/Kota merupakan salah satu upaya dari pemerintah pusat untuk meningkatkan kualitas dan pemerataan pelayanan program keluarga berencana dan keluarga sejahtera, tetapi ketentuan tentang Standar Pelayanan MinimalBidang Keluarga Berencana dan Keluarga Sejahtera belum memenuhi asas perikemanusiaan dan Hak Asasi Manusia, seperti yang terdapat pada undang-undang No 52 tahun 2009 tentang Perkembangan Kependudukan dan Pembangunan Keluarga Sejahtera. Pertama,pembatasan standar pelayanan minimal bidang KB dan KS yang hanya meliputi pelayanan kontrasepsi dan balita, remaja dan usia lanjut serta ketahanan keluarga tanpa pelayanan kesehatan reproduksi yang lain. KIE tentang Keluarga Berencana dan Keluarga Sejahtera belum memperlihatkan standar yang tepat. Kedua, dengan adanya indikator dan target dalam peningkatan peserta KB yang ingin dicapai pada SPM bidang KB dan KS, mengandung unsur bahwa pemerintah berupaya memaksakan keinginannya untuk mengatur hak-hak reproduksi perempuan, sehingga berdampak pada terlanggarnya asas perikemanusiaan dan hak asasi manusia untuk mendapatkan kesetaraan dan kebebasan dalam menentukan keputusan akan kehidupan berkeluarga.

\section{Saran}

Dari hasil penelitian dan kesimpulan tesis ini, dapat dirumuskan beberapa saran sebagai berikut:

1. Para pemegang kebijakan di pusat:

a. Agar segera menindaklanjuti setiap peraturan perundang-undangan yang terkait dengan standar pelayanan minimal sehingga tidak terulang kembali keterlambatan penyusunan peraturan pada pemerintah daerah, yang berdampak pada lambatnya pencapaian target dari SPM itu sendiri.

b. Agar melengkapi kebijakan tentang standar pelayanan minimal dengan pedoman pelaksanaan yang jelas dan akurat.

c. Perlu sosialisasi peraturan-peraturan tentang asas perikemanusiaan dan hak asasi manusia kepada seluruh tenaga pelaksana pelayanan KB dan Keluarga Sejahtera, sehingga tidak ada lagi tenaga yang melanggar peraturan-peraturan tersebut yang pada akhirnya hak asasi manusia dapat dilindungi dan dijunjung tinggi.

2. Kepada pemerintah provinsi agar menyusun petunjuk pelaksanaan dan petunjuk teknis standar pelayanan minimal bidang Keluarga Berencana dan Keluarga Sejahtera yang berdasarkan peraturan pemerintah tentang standar pelayanan minimal.

3. Kepada pemerintah daerah kabupaten/kota agar menyusun peraturan daerah atau surat keputusan bupati/walikota yang berhubungan dengan Standar Pelayanan Minimal Bidang Keluarga Berencana dan Keluarga Sejahtera dan sebaiknya pemerintah daerah menjadikan program KB sebagai sentral pembangunan di daerah. Kepada bupati/walikota, DPRD selaku pengambil kebijakan di daerah dan para pengelola program KB dan KS yang bertugas pada lembaga pengelola Program KB dan KS kabupaten/kota agar dapat mendukung program KB dan KS dengan sungguh-sungguh melalui pengadaan sarana prasarana kantor, pengadaan alat kontrasepsi, dana operasional perlu ditingkatkan, rekrutmen PLKB/PKB baru untuk 
ditempatkan di desa/kelurahan secara ideal dan rasional, perkuat keberadaan Institusi Masyarakat Perkotaan/Pedesaan (IMP), dan mendukung kegiatan pendataan keluarga setiap tahun.

\section{DAFTAR PUSTAKA}

Badan Pusat Statistik dan Macro International. 2008. Survey Demografi dan Kesehatan Indonesia 2007.Calverton, Maryland USA, BPS dan Macro International.

BPS, BKKBN, Kementerian Kesehatan. 2013. Survey Demografi dan Kesehatan Indonesia 2012. Calverton, Maryland USA, BPS dan Macro International.

BKKBN, Rencana aksi bidang KB dan KR tahun 2012-2014, 2012, Jakarta, BKKBN

Kementrian Pendidikan dan Kebudayaan. 2013. Materi Ajar Mata Kuliah Pancasila. Direktorat Pembelajaran Dan Kemahasiswaan Direktorat Jenderal Pendidikan Tinggi Departemen Pendidikan Nasional Kementerian Pendidikan Dan Kebudayaan Republik Indonesia. Jakarta

Kemitraan bagi Pembaruan Tata Pemerintahan. 2009. Belajar Dari 10 Provinsi. Cet.I. Jakarta : Kemitraan

Mustakim, 2012, Cakrawala KB Kependudukan dan Pemberdayaan Keluarga, Jakarta : Referensi.

Nung Ati N, 2012, Ketentuan Tentang Keluarga Berencana Dan Asas Nondiskriminasi Dikaitkan Dengan Hak Reproduksi Perempuan, Tesis: Fakultas Ilmu Hukum Unika Soegijapranata Semarang.

Ratna Batara Munti, 2010, Mewujudkan Hak Perempuan Atas Kesehatan Reproduksi dan Seksual Sebagai HAM, Jaringan Kerja Prolegnas Pro Perempuan/Federasi LBH APIK

Sri Yuliani,2006, Perempuan dan Kebijakan Pengendalian Kelahiran, Jurnal Penduduk dan Pembangunan, LIPI.go.id

Sunarti E, 2011, Kependudukan dan Keluarga Sejahtera, Isu Strategis Dalam Analisis dampak Kependudukan Terhadap Aspek Sosial Ekonomi, BKKBN.

UNDP. 2013, Human Development Report 2012 Sustainability and Equity: A Better Future For All. New York: UNDP.

\section{Peraturan- peraturan}

Peraturan Daerah Provinsi Jawa Barat Nomor 53 Tahun 2008 tentang Urusan Pemerintahan Provinsi Jawa Barat

Peraturan Pemerintah Republik Indonesia Nomor 65 Tahun 2005 tentang Pedoman Penyusunan dan Penerapan Standar Pelayanan Minimal

Peraturan Kepala BKKBN No55/HK-010/B5/2010 Tahun 2010 tentang Standar Pelayanan Minimal Bidang Keluarga Berencana dan Keluarga Sejahtera di Kabupaten/Kota.

Peraturan Menteri Dalam Negeri Nomor 62 Tahun 2008 tentang Standar Pelayanan Minimal Bidang Pemerintahan Dalam Negeri di Kabupaten/Kota.

Peraturan Menteri Kesehatan RI Nomor 741/MENKES/PER/2008 tentang Standar Pelayanan Minimal Bidang Kesehatan di Kabupaten/Kota.

Undang-Undang Nomor 39 tahun 1999 tentang Hak Asasi Manusia.

Undang-Undang Republik Indonesia Nomor 32 Tahun 2004 tentang Pemerintah Daerah.

Undang-Undang Nomor 52 tahun 2009 tentang Perkembangan Kependudukan dan Pembangunan Keluarga.

UUD 1945 \& Amandemennya, Edisi Terbaru, Yogyakarta : Laras Media Prima 